\title{
Metropolização e planejamento territorial como perspectiva de desenvolvimento em Angola
}

Metropolization and territorial planning
as a development perspective in Angola

José Caléia Castro [I]

Paulo Romano Reschilian [II]

\section{Resumo}

0 processo de metropolização e crescimento econômico de Angola desde o pós-guerra (2002) motivou a elaboração do planejamento territorial como estratégia para o desenvolvimento urbano/regional. Este trabalho analisa as ações de planejamento e desenvolvimento das realidades do Sul global, a partir do estudo dos processos de metropolização de Luanda, num contexto em que se intensificam o crescimento demográfico e a urbanização informal. Embora seja uma das maiores expressões das assimetrias e precariedades socioespaciais contemporâneas, Luanda convive com as aspirações do desenvolvimento urbano pós-moderno e neoliberal trazidas pelas pressões da globalização. Por meio da aplicação de uma metodologia mista, constatou-se que o pensamento tecnocrata neoliberal aplicado ao planejamento dessas realidades debate-se com a predominância estrutural da informalidade e configura um espaço híbrido.

Palavras-chave: Angola-Luanda; desenvolvimento regional; metropolização; planejamento urbano; planejamento híbrido.

\begin{abstract}
The process of metropolization and economic growth in Angola since the post-war period (2002) has motivated the creation of territorial planning as a strategy for urban/regional development. This work analyses the planning and development actions of the Global South realities, based on the study of Luanda's metropolization processes, in a context where demographic growth and informal urbanization have increased. Although it is one of the greatest expressions of socio-spatial asymmetries and precariousness, Luanda coexists with the aspirations of postmodern and neoliberal urban development brought about by the pressures of globalization. Through the application of a mixed methodology, it was found that neoliberal technocratic thinking applied to the planning of these realities struggles with the structural predominance of informality and configures a hybrid space.
\end{abstract}

Keywords: Angola-Luanda; regional development; metropolization; urban planning; hybrid planning. 


\section{Introdução}

A atual conformação socioespacial de Angola é resultado do seu processo histórico baseado nos impactos do período colonial (14821975), marcado principalmente pelo planejamento excludente e as guerras de libertação nacional (1961-1975), mas, também, das cerca de três décadas de guerra civil (1975$2002)^{1}$ que (des)arranjaram as dinâmicas urbano/regionais, políticas, socioeconômicas e culturais. Este trabalho analisa as dinâmicas urbano/regionais e as ações de planejamento e desenvolvimento em Luanda, Angola, e demonstra como o processo de metropolização se constitui no elemento crucial para o estudo socioespacial e o desenvolvimento dessa realidade.

Nos últimos 16 anos do pós-guerra civil, a ideia de planejamento e desenvolvimento urbano/regional de Angola respaldou-se no cenário econômico impulsionado pelos ganhos da exploração do petróleo verificado, principalmente, no período de 2002-2014. Parece evidente ser esse o fator econômico mais importante do pós-guerra que, quando analisado, é capaz de revelar as potencialidades e/ ou debilidades estruturais que determinaram o desenvolvimento e a conformação do espaço urbano/regional.

Além de aspectos como a colonização portuguesa e a prolongada guerra civil, fatores como: o êxodo rural; a intensa migração interna em direção a Luanda; o crescimento polarizado da economia; o modelo de gestão territorial baseado no sistema de poder centralizado de partido único, ideologicamente fundamentado no modelo do socialismo marxista leninista; "bem como a natureza da política econômica seguida até meados dos anos 1990" (Rocha, 2010 p. 18) são fundamentais para a compreensão do atual cenário socioespacial marcado pela informalidade e precariedade.

Mas se, por um lado, a guerra e o "comportamento político ostensivamente cego perante os problemas do interior do país" (Rocha, 2010 p. 18) foram cruciais para o agravamento e a permanência da precariedade e dos desequilíbrios territoriais, por outro, o fator econômico adaptado às necessidades do capitalismo neoliberal contemporâneo, acolhido pela necessidade ou pela cobiça do crescimento e da prosperidade no pós-guerra, produziram uma utopia de desenvolvimento marcado pela instabilidade socioeconômica e por incongruências no desenvolvimento urbano. Cenário que, segundo Bresser-Pereira (2004), são próprios dos países da periferia do capital, devido aos problemas estruturais e da dependência a que estão submetidos.

Em Angola, o discurso do planejamento territorial como estratégia para o desenvolvimento equalizado, apresentado pelo Plano Nacional de Desenvolvimento 2013-2017 (Angola, 2012) ganhou força, principalmente, para Luanda, que se configura não apenas como principal polo econômico, mas, também, como centro do planejamento territorial que assume uma característica semelhante ao que Perroux (1950, p. 93) chamou de "área relativa à execução de um plano, campo de forças e estrutura com características próprias". Ou seja, Luanda passou a ser a principal e talvez a única subunidade de planejamento de Angola. Uma condição que se consolidou com o advento da paz (2002), período em que o Estado passou a desfrutar de condições político-administrativas para avaliar e apresentar estratégias de contraposição aos crescentes desequilíbrios 
urbano/regionais. Porém o que ocorre na prática é a intensificação e a perpetuação da polarização de Luanda, transformando-a em centro hegemônico do poder em todos os níveis (Oliveira, 2015); uma Cidade-Estado contemporânea. Luanda é, nesse contexto, um verdadeiro caso de macrocefalia urbano/regional.

Por seu turno, o processo de metropolização de Luanda é resultante de um acelerado processo de urbanização intensificado pelo crescimento demográfico, as conurbações, a intensificação das trocas socioeconômicas, as complexidades dos sistemas de mobilidade baseados nos modos de circulação e transporte informal (Castro, Reschilian e Zanetti, 2018). E a complexidade da divisão social do trabalho, diante das nuances das lógicas globais contemporâneas de planejamento e gestão do território, produz, para as realidades periféricas do Sul global, como Luanda, uma metrópole precária e informal (Amaral, 2005; Davis, 2006).

Assim, apesar de seu impacto e importância, as perspectivas de planejamento e desenvolvimento apresentadas pelos instrumentos de regulação da produção do espaço urbano/regional, tais como: o Plano Nacional de Desenvolvimento (PND), de 2013-2017 (Angola, 2012), ou o Plano Diretor Geral Metropolitano de Luanda (PDGML) de 2015-2030 (Luanda, 2015), não são, na prática, os responsáveis pelo processo de metropolização que ocorre em Luanda. Mas sim, as influências do contexto histórico, das relações socioculturais, político/econômicas e as dinâmicas urbanas quotidianas sustentadas na informalidade. E, embora considerem-se as sequentes tentativas de planejamento engendradas ao longo da história desde 1940, fato é que costumeiramente tais planos se configuraram mais em modelos segregacionistas e incapazes de acomodar o crescimento contínuo da população e suas nuances socioespaciais (Development Workshop, 2005).

É, nesse ínterim, que se propõe discutir e analisar o planejamento e o desenvolvimento territorial de Angola, a partir da busca do entendimento de como o processo de metropolização de Luanda, baseado na informalidade, constitui-se em fator fundamental para o planejamento e desenvolvimento urbano/ regional de Angola e as metrópoles periféricas do Sul global. Questão que, por outro lado, sugere os seguintes objetivos específicos:

(a) abordar a regionalização e a metropolização no contexto do Sul global;

(b) analisar a conformação urbana de Luanda como produto das dinâmicas endógenas e das nuances globais;

(c) analisar o planejamento metropolitano como perspectiva de desenvolvimento.

Por fim, as considerações finais remetem à reflexão sobre os assuntos abordados com enfoque para o planejamento do processo de metropolização como fundamentais para o desenvolvimento urbano e regional.

\section{Metodologia}

Para este estudo, foi utilizada a metodologia mista, que consistiu no trabalho empírico realizado por meio das relações e vivências na área de estudo em junho de 2015, maio de 2016 e setembro de 2019; estudo bibliográfico/ documental; entrevistas semiestruturadas dirigidas aos agentes governamentais e da sociedade civil organizada, tais como: Ministério do Planeamento e Desenvolvimento Territorial, Direção Nacional dos Transportes Rodoviários, Direção Nacional do Comércio, Development 
Quadro 1 - Instituições colaboradoras na pesquisa de campo

\begin{tabular}{|l|l|}
\hline \multicolumn{1}{|c|}{ Instituição/Agente/local } & \multicolumn{1}{c|}{ Atividade } \\
\hline $\begin{array}{l}\text { Instituto Nacional dos Transportes Rodoviários - INTR, } \\
\text { Luanda }\end{array}$ & $\begin{array}{l}\text { Entrevista/conversa - Diretora nacional dos transportes } \\
\text { de Luanda }\end{array}$ \\
\hline Direção Nacional do Comércio & $\begin{array}{l}\text { Entrevista/conversa e passeio pelos pontos “nodais" da } \\
\text { cidade - Diretor nacional do comércio interno }\end{array}$ \\
\hline $\begin{array}{l}\text { Ministério do Planeamento e Desenvolvimento } \\
\text { Territorial }\end{array}$ & Entrevista/conversa - Diretor setorial \\
\hline Development Workshop (DW-Angola) & $\begin{array}{l}\text { Entrevista/conversa, debates, aquisição de dados } \\
\text { geoespaciais - Diretor nacional da DW }\end{array}$ \\
\hline $\begin{array}{l}\text { Ceic-Ucan I Centro de Estudos e Investigação Científica } \\
\text { da Universidade Católica de Angola }\end{array}$ & $\begin{array}{l}\text { Instituição coparticipante: entrevista/conversa com os } \\
\text { professores da área de economia, política, sociologia e } \\
\text { antropologia. Aquisição de dados bibliográficos }\end{array}$ \\
\hline
\end{tabular}

Fonte: elaboração própria, em 2019.

Workshop (DW-Angola), Centro de Investigação Científica da Universidade Católica de Angola (Ceic/Ucan) (Quadro 1).

Fez-se o uso das ferramentas do SIG (Sistema de Informações Geográficas) para análise, elaboração, quantificação e qualificação de dados geoespaciais. Considerou-se o método misto como base para a sistematização do estudo, por ser um procedimento que, de acordo com Christensen et al. (2011), permite o uso de múltiplas aplicações, técnicas e esforços interdisciplinares e combinados para uma compreensão mais alargada e efetiva.

\section{Regionalização e metropolização}

Os países do Sul global apresentam um grande desafio quanto à conceituação dos fenômenos socioespaciais contemporâneos, devido ao intenso, complexo e difuso processo de urbanização influenciado pela "des-ruralização contemporânea e a incorporação do campo à expansão das fronteiras mundiais" (Ribeiro e Santos Júnior, 2010, p. 21; grifos meus). Processos que vinham durante muito tempo sendo excluídos das discussões globais de urbanização, mas que passaram a ser reconsiderados devido não apenas ao impacto das rápidas transformações impostas ao atual modelo de urbanização global (Jaglin, Didier, Dubresson, 2018) caracterizada, nessas realidades, pela controvérsia da predominância da urbanização informal (Roy, 2005) com as ideias do planejamento futurista contemporâneo (Watson, 2014).

Nos países da África tropical, do qual Angola faz parte, o debate de regionalização começa a ter repercussão "a partir de 1960, quando se inicia a onda de independências desses países" (Rochefort, 2003, p. 115), que passam a experimentar, nesse período, grandes mudanças estruturais, políticas, econômicas e sociais. Dessa forma, o desafio é entender não apenas as dinâmicas e implicações das múltiplas interpretações, mas a ressignificação das relações das identidades dos sujeitos 
materiais e imateriais desses espaços com a região que sujeita esse conceito a uma variabilidade histórica, cultural e geográfica (Souza, 2013). Segundo o autor, o entendimento da questão da região não se limita à compreensão do fator geográfico ou da escala em si, mas também de outros aspectos socioespaciais, econômicos e de domínio técnico-científico. Para Freitas (2009, p. 45), a "região refere-se a uma área contínua com características de homogeneidade relacionadas ao domínio de um determinado aspecto, seja ele natural ou construído, econômico ou político". Por essa ótica, a região ganha maior amplitude e, ao mesmo tempo, preserva suas peculiaridades.

Algumas dessas peculiaridades, apesar de muito difusas (Caldeira, 2017), tornam as cidades do Sul global, como Luanda, uma região particular e ao mesmo tempo comum, que partilham características que vão além da sua periferização global ou endógena, como por exemplo o fator demográfico (Davis, 2006). Regiões que são consideradas ora como "metrópoles, megacidades ou megalópoles" - quando a dinâmica populacional prevalece sobre a dinâmica dos espaços urbanizados (Haeringer, 1998) - e ora como megacidades - quando constroem, por meio de suas características partilhadas, um espaço demarcado. Tais caracterizações são, por si só, uma ação de regionalização, pois configuram espaços globais que partilham elementos e características comuns e complexas em uma mesma categorização (Jaglin, Didier, Dubresson, 2018).

É preciso compreender que, na conjuntura contemporânea das realidades periféricas do Sul global, o conceito de regionalização demarca-se, invariavelmente, pela sua associação com a produção do espaço informal, precário e desigual (Watson, 2014; Myers, 2011; Roy, 2005; Cain, 2014; Piertese, 2011), que contrasta com as ideias ou utopias de desenvolvimento trazidas pela lógica do capitalismo neoliberal global.

De acordo com Ribeiro e Santos Júnior (2010), a organização dos territórios do Sul global enfrenta um distanciamento do desenvolvimento do progresso material e do bem-estar social cada vez maior, por debaterem-se com problemas de ordem estrutural. Tal distanciamento deixa atrelada a questão da regionalização a uma crise conceitual marcada pelo que os autores (ibid., p. 21) classificaram de "disjunção entre economia, sociedade e território". Segundo Costa (2013, p. 327), "toda região deveria pressupor uma intenção de intervenção e de gestão, estabelecendo elementos de controle e limites". Essas percepções desvendam um estado de ambiguidades entre o progresso material, demográfico e dos fluxos econômicos que dificulta o consenso conceitual de regionalização em suas diferentes escalas e processos.

Pode-se, então, dizer que a regionalização está ou deveria estar atrelada a um esforço criativo de conceber e reproduzir condições para a coordenação de macropolíticas para a gestão e o financiamento dos espaços principalmente metropolitanos, como as funções essencialmente urbanas (habitação, saneamento, mobilidade e transporte). E, dessa forma, o próprio conceito de metropolização passa a ser também objeto de reanálise, uma vez que o desenvolvimento de estruturas conceituais e perspectivas críticas devem levar em conta a diversidade das trajetórias urbanas na globalização.

A metropolização é um processo que altera e demarca ou regionaliza o território. Enquanto dinâmica urbana, está ligada à 
conjuntura da produção social do espaço, tais como: o crescimento demográfico, a intensa urbanização, a intensificação do enredo e debilidades da mobilidade urbana, os conflitos espaciais, a complexidade da divisão técnica e social do trabalho, segundo Singer (1998), atrelados aos fatores socioeconômicos de agentes com diferentes graus de capital, de tecnologia e de organização (Silveira, 2015).

A metropolização também é considerada "uma metamorfose do processo de urbanização" (Lencioni, 2006, p. 72); quando origina uma ação de regionalização. Uma metamorfose que, segundo a autora, retira do espaço características anteriores, "arcaicas ou tradicionais" e incorpora e desenvolve outras (com novas relações entre capital-sociedade, objeto-espaço). De alguma forma, essa colocação, do modo como entendida, não se constata nas realidades desfavorecidas, precárias e superpopulosas das metrópoles do Sul global. No entanto, Lencioni (2015) sugere que a metropolização é um fenômeno hegemônico que sobrepõe a relação capital-metropolização numa racionalidade semelhante à lógica anterior do capital industrial relacionada com o processo de urbanização. Nesse caso e considerando o papel fundamental dos agentes estruturadores e as dinâmicas da produção do espaço urbano, compreende-se que não se trata da substituição do arcaico pelo novo na sua essência, mas pela incorporação de outras características (anteriores ou posteriores) e o desenvolvimento de outras (Ferreira et al., 2015).

A metrópole contemporânea apresenta como "uma espécie de tradução urbana da manifestação socioespacial da globalização" (Lencioni, 2006, p. 72). Assim, não há dúvidas de que o processo de metropolização esteja ligado à intensidade de fluxos demográficos, financeiros e mercadorias, bem como ao crescimento dos serviços, do trabalho de administração e gestão; e, cada vez mais, ao domínio das tecnologias da informação, o modo do consumo entre outros (ibid.). Segundo Moura (2009), a metropolização reflete uma fase mais evoluída da urbanização, manifestando uma pós-urbanização que evidencia uma nova época. Observa-se na colocação desse autor uma semelhança quanto ao conceito de metamorfose de Lencioni (2006). Somente que para Moura (2009), a ênfase está na "fase evoluída da urbanização" que, para Lencioni (2006), não é necessariamente um processo que traz o novo, mas apenas uma mudança de estado do espaço.

A questão do "pós-urbanização" (Moura, 2009) pressupõe uma evolução urbana no sentido estrutural do espaço. Porém, é preciso certa cautela na compreensão dessa abordagem, principalmente quando se fala de metropolização de países periféricos que mais se assemelham a um cenário de involução urbana - em que, por um lado, se busca o desenvolvimento de um espaço sob a racionalidade global e moderna, mas que, por outro, é fundamentado nas lógicas de estruturas arcaicas, precárias e informais que dominam a produção, a administração, o desenvolvimento e a exploração desses territórios (Watson, 2014; Myers, 2011).

A metropolização é um processo espacial que acontece no território e que altera as relações sociais, econômicas e culturais enquanto dinâmica urbana. Mas pode ser, também, apenas uma concepção institucional e meramente administrativa ou de interesse econômico que não converge para a transformação real das condições socioespaciais 
(Moura e Firkowski, 2001). Isto é, uma metropolização ex-post (Klink, 2013) em que se impõe, de maneira vertical, um planejamento autocrata e tecnocrata, apresentando as regiões metropolitanas como polos de desenvolvimento para integração da economia. Mas, para Klink (ibid.), a institucionalização da Região Metropolitana deveria estar ligada aos processos espaciais caracterizados pela intensa urbanização dos municípios ou aglomerados urbanos em que, dentro das articulações político-institucionais dos agentes e atores estruturadores do espaço, se construam as condições para a governança metropolitana que, no caso do Brasil, dá origem às chamadas Funções Públicas de Interesse Comum (FPIC) entre os municípios que compõem uma Região Metropolitana (RM).

As colocações de Klink (ibid.) corroboram, em certa medida, Braga e Carvalho (2004, p. 8) que definem uma região metropolitana como "um aglomerado urbano composto por vários municípios administrativamente autônomos, mas integrados física e funcionalmente, formando uma mancha urbana praticamente contínua". Isso se considerarmos essa continuidade como objeto da convergência entre as dinâmicas do processo de metropolização com as disposições legais/administrativas. Porém, nos países periféricos do Sul global, a governação e a administração metropolitana talvez sejam algumas das suas maiores dificuldades na organização e no desenvolvimento do território. Seja por não valorizarem ou por não amadurecerem o entendimento dos processos, políticas e relações urbanas que compõem esse fenômeno que vai além da mera definição legal (Santos, 1998), ou pelas suas próprias debilidades estruturais. Por esse motivo, tais realidades se debatem cada vez mais, com a dualidade construída entre as dinâmicas urbano/regionais e as estratégias político/administrativas do território.

Diante de tantos conceitos distintos, entende-se que, apesar de existirem elementos centrais a serem considerados na abordagem dos autores, a questão da regionalização e da metropolização ainda permanece complexa, principalmente quando se trata das realidades periféricas. De toda forma, entende-se a metrópole como um produto dos processos de metropolização ligados às forças de produção e aos fatores que interferem nas dinâmicas e estruturação do espaço enquanto unidade contraditória e desigual da urbanização contemporânea, ao mesmo tempo que se configura como "uma esfera pública de disputa política da produção do espaço" (Barbosa, 2015, p. 171). Dessa forma, pode-se então afirmar que a regionalização não está desassociada da metropolização que, por sua vez, é amparada pelo espaço territorial delimitado, aqui entendido como metrópole. 0 que constitui, dessa forma, um plano tridimensional de relações espaciais complexas.

\section{Contexto histórico/espacial de Angola}

Embora a guerra seja o fator fundamental mais apontado como estruturante do espaço de Angola, sua atual caracterização pode ser abordada a partir dos seguintes fatores: o crescimento econômico verificado no período de 2002-2014, as desigualdades socioespaciais, a intensa urbanização de Luanda e a reconstrução nacional iniciada após os acordos de paz em abril de 2002. A esses 
fatores, soma-se ainda um quinto elemento importante para a compreensão das atuais dinâmicas políticas, socioeconômicas e espaciais: a inserção da China como principal parceiro econômico e a mais importante linha de crédito no processo de reconstrução de Angola (Rocha, 2010).

Angola possuía uma população estimada em cerca de 25 milhões de habitantes em 2015, contra os 5,6 milhões em 1970 (INE, 2014). Dessa população, $63 \%$ vivia em área urbana até 2016, apesar de se registrar, atualmente, uma regressão nesse crescimento no nível das províncias (61\% no período de 20162017 de acordo com INE, 2016), enquanto Luanda apresenta apenas 2,56\% de população rural e aponta para uma contínua progressão do crescimento da população urbana. Fato que não deve nos levar a concluir que a população de Angola seja maioritariamente rural, pois o total da população de Luanda, que é maioritariamente urbana, soma mais de $30 \%$ da população total do território nacional, atualmente com cerca de mais de 30 milhões de pessoas, segundo o Banco Mundial (2020). Tais percentuais agregados ao restante da população urbana das outras províncias resultarão na prevalência da população urbana.

0 país está constituído por 18 províncias subdivididas, ao todo, em 162 municípios e 559 comunas (Figura 1), divididas em localidades urbanas e rurais. Foi subdivido em 70.287 Secções Censitárias (Censo Demográfico de 2014), segundo a divisão político-administrativa.

Os governos provinciais que são, em termos hierárquicos, a segunda maior dimensão na administração pública e territorial engendram, acima de tudo, os anseios político-partidários do Governo, antes mesmo de atender às principais necessidades da população amparadas pelo Estado. 0 governador provincial assume, costumeiramente, um papel duplo: como primeiro secretário do partido no poder e como governador da província $^{2}$ (Kaliengue, 2016). Esse fato se estende para outras esferas institucionais, ${ }^{3}$ comprometendo, assim, a governabilidade e a gestão do território.

Em Angola, há um excesso de interferência e controle do governo nas dinâmicas da produção do espaço, que é resultante da lógica de uma administração vertical de estilo monárquico a que o país esteve submetido desde a independência (1975). Por um lado, entende-se como uma herança do modelo colonialista português; por outro, da própria cultura nacional; e, por fim, da influência do sistema socialista e monopartidário que dominou entre 1975 e 1991. É sob essa lógica de organização e administração do território que se desenvolveu o planejamento que Pereira (2013) chamou de planejamento de cima para baixo; em que "a realização de mudanças ignora a opinião dos beneficiários, [tais mudanças] são artificiais e mais propensas ao fracasso" (ibid., p. 249). Um ponto comum aos países africanos e crucial para discutir o planejamento e desenvolvimento socioespacial dessas realidades.

Apesar de sua inserção na economia global, devido ao setor diamantífero e petrolífero do qual é totalmente dependente, Angola tem sofrido com uma crise socioeconômica crônica desde 2014, deixando de ser o país que tão recentemente (2002-2013) vivenciou uma "era de ouro" devido aos rendimentos do alto preço do petróleo nesse período. No entanto, não foi capaz de efetuar mudanças estruturais, diversificar a economia, diminuir significativamente a pobreza e a precariedade 
Figura 1 - Cartograma de municípios, comunas e localidades por província - 2014

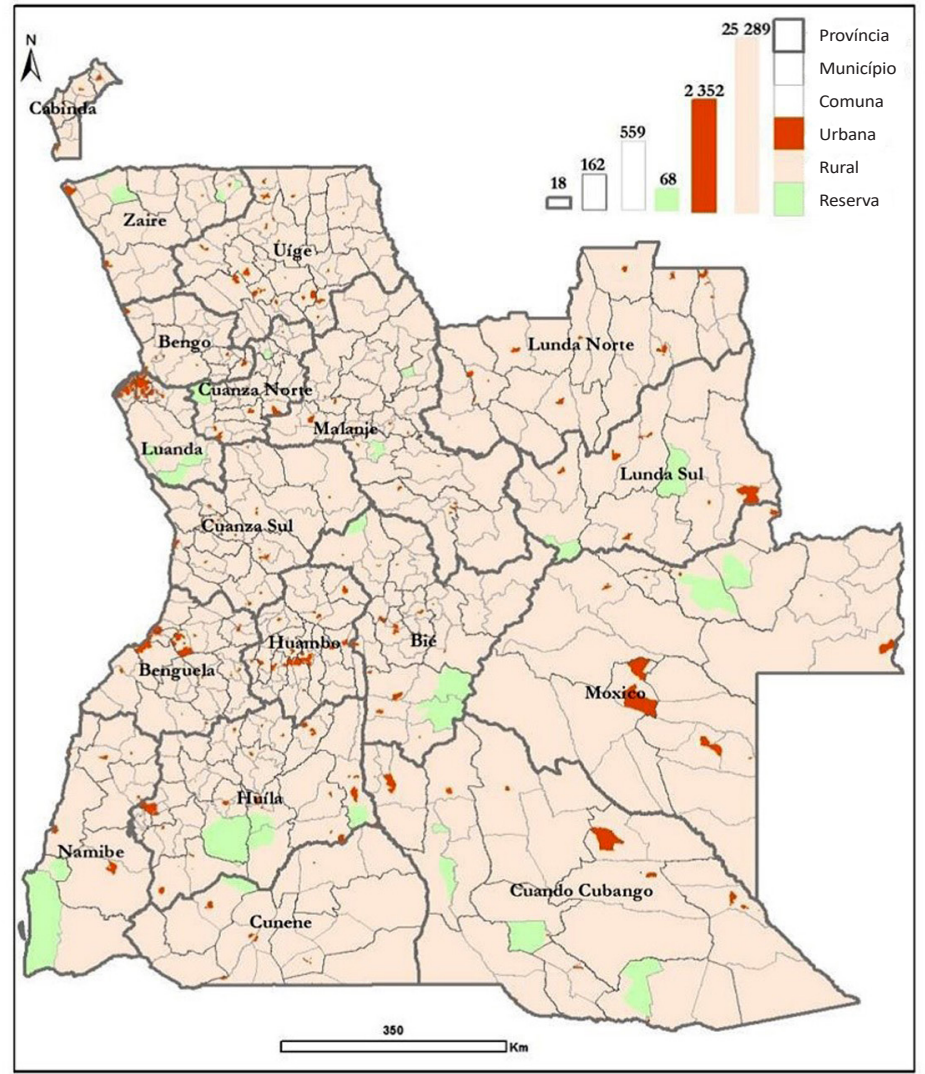

Fonte: INE - Instituto Nacional de Estatística (2014).

urbano/social; ainda que, de alguma forma, tenha-se reconfigurado o mapa da pobreza extrema com a influência da informalidade e o advento da livre circulação de pessoas e bens (Castro, 2015), Angola ainda faz parte dos países com pior índice de desenvolvimento urbano ou socioeconômico. Uma condição refletida na flexibilidade e precarização do trabalho, nos índices de pobreza social de $36,6 \%$ (segundo o Ibep, 2008-2009), com 60\% da população vivendo com menos de dois dólares por dia (Rocha, 2017), numa realidade cujo Índice de Desenvolvimento Humano (IDH) é de 0,526 desde 2013 (PNUD, 2014). A diferença entre o IDH e o PIB por habitante foi de USD 6.532,5 em 2014 (Rocha, 2014), e a taxa média anual foi de $12,5 \%$, entre 2004 e 2008 , e de $3,4 \%$ entre 2009 e 2014 (Rocha, 2015). 
Segundo Furtado (2002, p. 32), "as economias subdesenvolvidas podem conhecer fases prolongadas de crescimento de seu produto global e per capita, sem reduzir o grau de dependência externa e a heterogeneidade estrutural interna, que são suas características essenciais". Exemplo dessa dependência que, por um certo olhar, pode ser considerada deletéria e, ao mesmo tempo, benéfica são as atuais e complexas relações de trocas financeiras/econômicas mantidas entre a China e Angola, permeadas por obscuridade e desequilíbrio no protagonismo das relações. Apesar de ser o favorecedor das oportunidades de exploração, Angola não consegue preservar sua soberania e integridade equânime nas negociações de modo a preservar sua integridade socioespacial e econômica diante de uma China que se apresenta como a égide do tão almejado desenvolvimento. 0 desequilíbrio dessas relações refletem-se nas diversas dimensões do espaço urbano, em que atores privados e governamentais procuram unir-se aos interesses chineses para engendrar ações de acumulação de recursos por meio da exploração do próprio território, gerando, assim, riquezas que não se revertem em desenvolvimento do país, mas que o mantêm refém de

um processo de acumulação primitiva de capital que criou uma classe minoritária de ricos e afortunados que escolhem investir fora do país (Portugal de preferência), em vez de injectarem os milhares de milhões de dólares na diversificação das exportações de Angola. (Rocha, 2015, p. 4)

Ao investirem e acumularem recursos e finanças fora do país, em vez de proporcionarem um reinvestimento que vise ao desenvolvimento nacional, os agentes do poder econômico, financeiro e político acabam por debilitar a economia do país e o estado social da população mais vulnerável que carece de acesso aos direitos sociais básicos, gerando

uma situação de privação de algumas dimensões do bem-estar de um indivíduo, como acesso limitado a serviços de saúde, baixo capital humano, habitação inadequada, má nutrição, falta de determinados bens e serviços, falta de capacidade para expressar pontos de vista políticos ou professar credos religiosos, etc. (INE, 2011, p. 165)

A desigualdade social agravada pela corrupção e pelo tráfico de influência, somada à incapacidade de converter os rendimentos econômicos e financeiros em políticas redistributivas para a melhoria do bem-estar das populações é, segundo Rocha (2015), resultado de um governo pouco comprometido de fato com o desenvolvimento regional equilibrado que tanto paira em seus discursos políticos de planejamento. 0 autor aponta, ainda, o reflexo do apego a atitudes paternalistas principalmente de uma elite minoritária ligada ao poder político e explica que: "já se criou a cultura de dependência do Estado, no sentido de que tudo tem de ser de sua responsabilidade" (ibid., p. 217). E, embora essa realidade esteja no enfoque de mudanças do atual governo liderado por João Lourenço (2017 - atual), a questão é que essa racionalidade é estrutural e comum entre os empresários que dependem ou valem-se do aparelho do Estado para engendrar seus anseios particulares. Todo esse contexto desafia e contrasta com as pretensões de desenvolvimento urbano/regional moderno, proposto pelos planos: PDGML 2015-2030 e o PND 2012-2017. 


\section{Conformação urbano/ metropolitana de Luanda}

Luanda, capital de Angola, está constituída por 7 municípios (Quadro 2): Belas, Cacuaco, Cazenga, Icolo, Bengo, Quissama, Luanda e Viana. Destes, os mais populosos são os municípios (sede) de Luanda e de Viana, que se configura um subcentro no contexto metropolitano.

Localizada na região litorânea do país (Figura 2) "a província de Luanda é a mais populosa, com 6.945,386 pessoas em 2014, representando pouco mais de um quarto da população do país nesse período (27\%)" (INE, 2014, p. 32). Dessa população, 70,9\% encontrava-se a viver em habitação construída com material não apropriado (Cain, 2013; INE, 2014). Um quadro que se agrava cada vez mais, não apenas devido ao aumento da população nacional projetada para 29.250,009 em 2018 (INE, 2018) e para cerca de 12 milhões, em 2030, para Luanda (IPGUL, 2015), mas, principalmente, devido à atual conjuntura social e político-econômica do país, embrenhada de sucessivos episódios e revelações de esquemas de corrupção sistêmica que contribuem para a piora da vida social da população.

Paradoxos amplamente evidenciados na vida quotidiana de Luanda. Apesar do esforço do Estado em apresentar uma nova imagem da cidade por meio de elementos da modernidade, como grandes e novos edifícios sofisticados, condomínios residenciais de alto padrão, a presença de automóveis supermodernos na malha viária, bem como o novo habitus consumista e imediatista (Schubert, 2016) de uma pequena parcela da população mais abastada, é na informalidade que se evidencia a racionalidade da produção do espaço urbano.

Existe, no entanto, outro fator com o qual Luanda se debate: o desequilíbrio da distribuição populacional. De acordo com a (Figura 3), Luanda possui "368 habitantes por quilômetro quadrado. Cerca de 18 vezes superior à média do país" (INE, 2014 p. 35).

A distribuição populacional é um fator importante para o planejamento e o desenvolvimento regional, uma vez que influencia nas demandas dos fluxos socioeconômicos.

Quadro 2- Número de municípios, comunas e localidades de Luanda, 2014

\begin{tabular}{|c|c|c|c|c|}
\hline \multirow{2}{*}{ Municípios } & \multirow{2}{*}{ Comunas } & \multicolumn{3}{|c|}{ Localidades } \\
\cline { 3 - 5 } & & Urbanas & Rural & Total \\
\hline 7 & 32 & 292 & 296 & 588 \\
\hline
\end{tabular}

Fonte: RGPH (INE, 2014). Elaboração própria, em 2016. 
Figura 2 - Localização de Luanda no contexto territorial de Angola - 2016
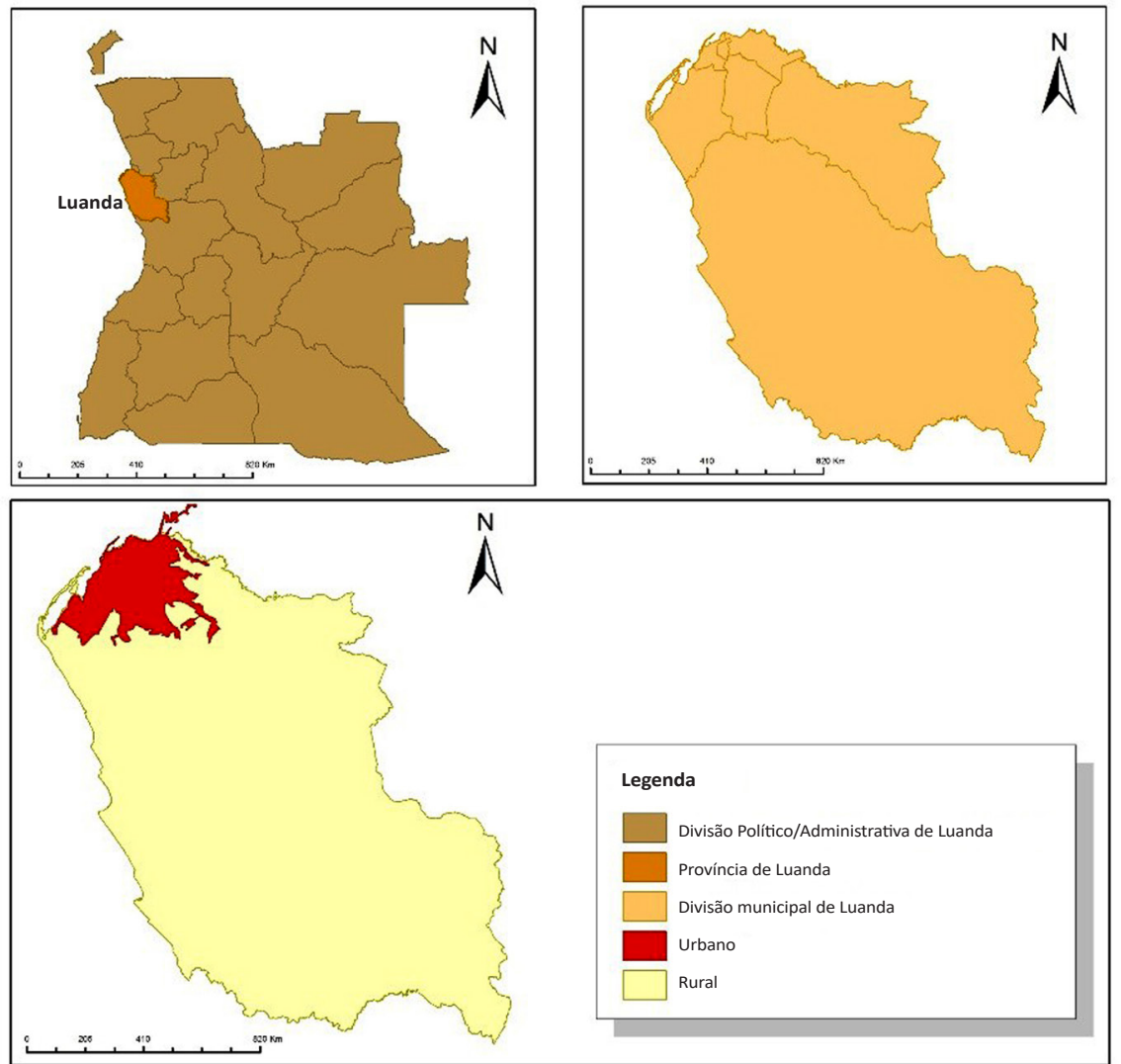

Fonte: elaboração própria, em 2016.

No entanto, o quadro apresentado por Luanda revela a presença de uma macrocefalia urbana que compromete as potencialidades do desenvolvimento.

A constituição da região metropolitana de Luanda como unidade administrativa autônoma convive com limitações de instrumentos legais e conceituais que clarifiquem as funções dos atores e as relações entre as cidades que compõem a RM. Embora se possa verificar a ocorrência efetiva do fenômeno de metropolização, segundo os princípios conceituais abordados, seu respaldo nos planos (PDGML 2015-2030 e PND 2013-2017) carece 
Figura 3 - Densidade demográfica por província, 2014

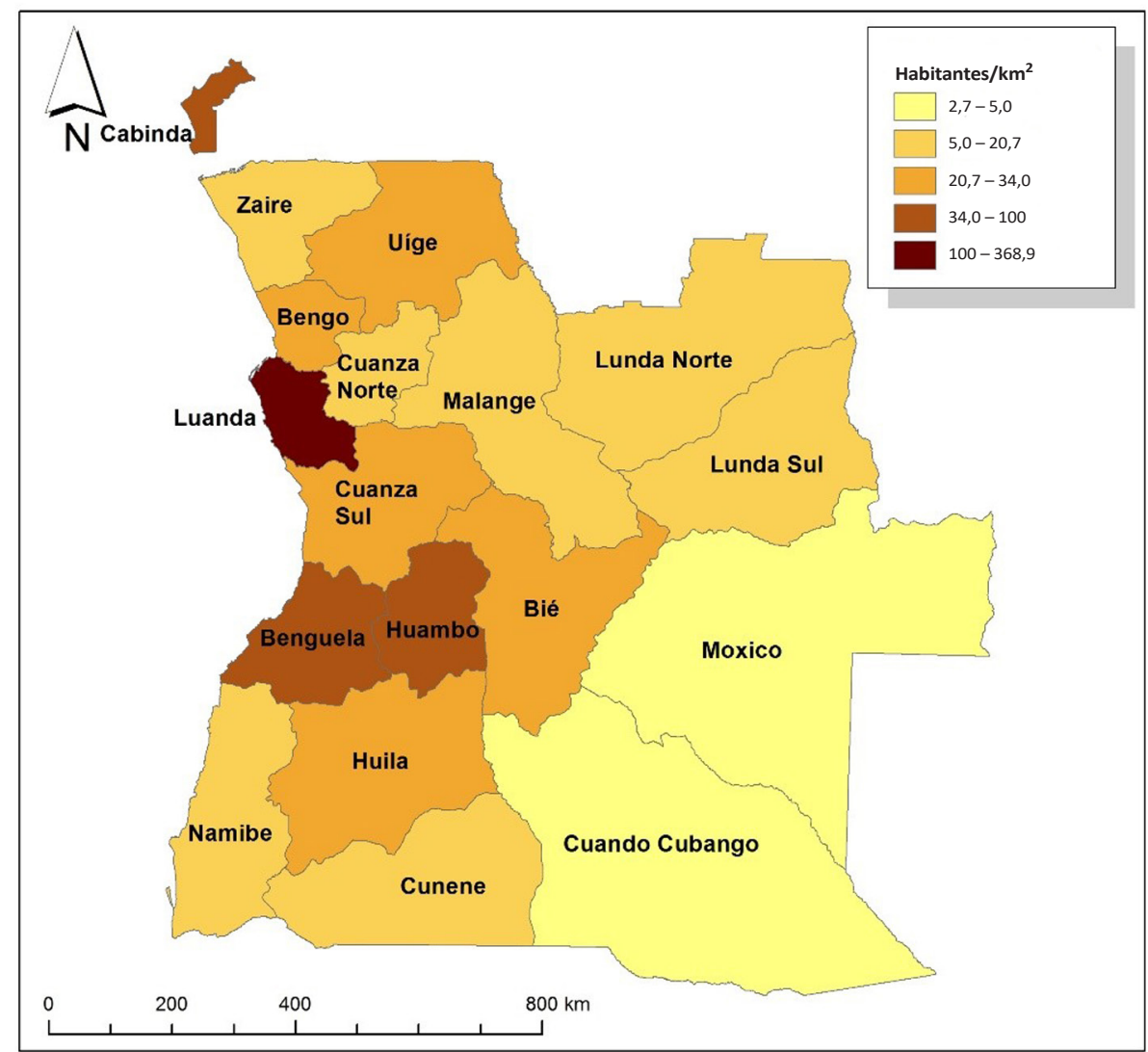

Fonte: elaboração própria, em 2016, com base no Censo Demográfico de 2014.

de estudos e debates aprofundados capazes de definir o tipo e as peculiaridades dessa metrópole. Essa definição é importante para que se estabeleça como fator catalisante do desenvolvimento equânime.

Assim, verifica-se, diante dos processos e variantes que constituem o espaço de Luanda, um processo dialético-diacrônico, ainda que este não seja único aos países periféricos, ao mesmo tempo que não se pode dizer que tais processos sejam uma norma para as realidades periféricas do Sul global, uma vez que a própria globalização é um processo com "positividades" e "negatividades", assim como a cidade é um espaço de antagonismos e diferenças. 


\section{Planejamento e desenvolvimento urbano e regional}

Quando se trata das cidades do Sul global, é comum observar em argumentos acadêmicos e discursos políticos, assim como no senso comum, a ideia de falta de planejamento na estruturação do espaço, criando uma narrativa de "desorganização" ou "desestruturação" urbana. Porém, sabe-se que a organização do espaço envolve "atividades e decisões complexas a respeito do uso e da ocupação do solo, mas também das dinâmicas da produção socioespacial. Os instrumentos reguladores do uso e ocupação do solo são produzidos por códigos e leis que definem a conformação urbana desejada ou permitida (Vasconcellos, 2012, p. 216) dentro de um contexto histórico, político, socioeconômico e cultural; aspectos fundamentais na produção e conformação do espaço urbano.

Houve, no caso de Luanda, ao longo do seu processo de urbanização, várias tentativas e ações de planejamento. Apesar de segregacionistas, os planos da época colonial foram dos poucos que maior impacto tiveram na definição da conformação urbana de Luanda. Havia, já na década de 1940, um plano urbano que ficou rapidamente ultrapassado e foi seguido por cinco versões até 1963 , não tendo qualquer um deles conseguido regular o crescimento urbano (Development Workshop, 2005). Os "musseques" ${ }^{4}$ (favelas), bairros periféricos precários, são, em parte, resultado da política adotada nos planos segregacionistas coloniais que se agravaram posteriormente com os efeitos da guerra e o modelo de gestão territorial, como já abordado. Embora o plano de 1973 reconhecesse, pela primeira vez, a necessidade de melhorar e não de deslocar os musseques, contrariamente ao que era geralmente feito nos planos anteriores, isso também nunca foi aplicado.

Esta análise demonstra que, em países subdesenvolvidos, a produção do espaço urbano nem sempre tem a ver com a elaboração de planos, mas principalmente com as dinâmicas e os processos socioespaciais ora espontâneos, ora imbuídos na lógica capitalista global de exploração dos territórios (Santos, 2000). Os planos de desenvolvimento urbano elaborados após a independência (1975) não surtiram os efeitos desejados, tampouco tiveram aplicabilidade integral (Development Workshop, 2005; Betencourt, 2011) mesmo com a situação de guerra que o país vivenciou durante 27 anos, Luanda conheceu, em 1979 e 1980, outros planos que visavam à reorganização do território (Figuras 4 e 5). Segundo a Development Workshop (2005, p. 73) "no ano de 2000 (dois anos antes do término dos conflitos civis bélicos), o Conselho de ministros aprovou um Plano de Gestão do Crescimento Urbano de Luanda, que viria a constituir a base para a elaboração de um novo plano piloto". ${ }^{5}$

A seguir, apresenta-se uma cronologia histórica (Quadro 3) que comprova a ocorrência de ações de planejamento que visavam ao desenvolvimento urbano de Luanda e que desconstrói o argumento da "falta de planejamento" como justificativa para o estado de precariedade, pobreza e informalidade do espaço urbano de Luanda. 
Figura 4 - Luanda - Plano Diretor de 1979

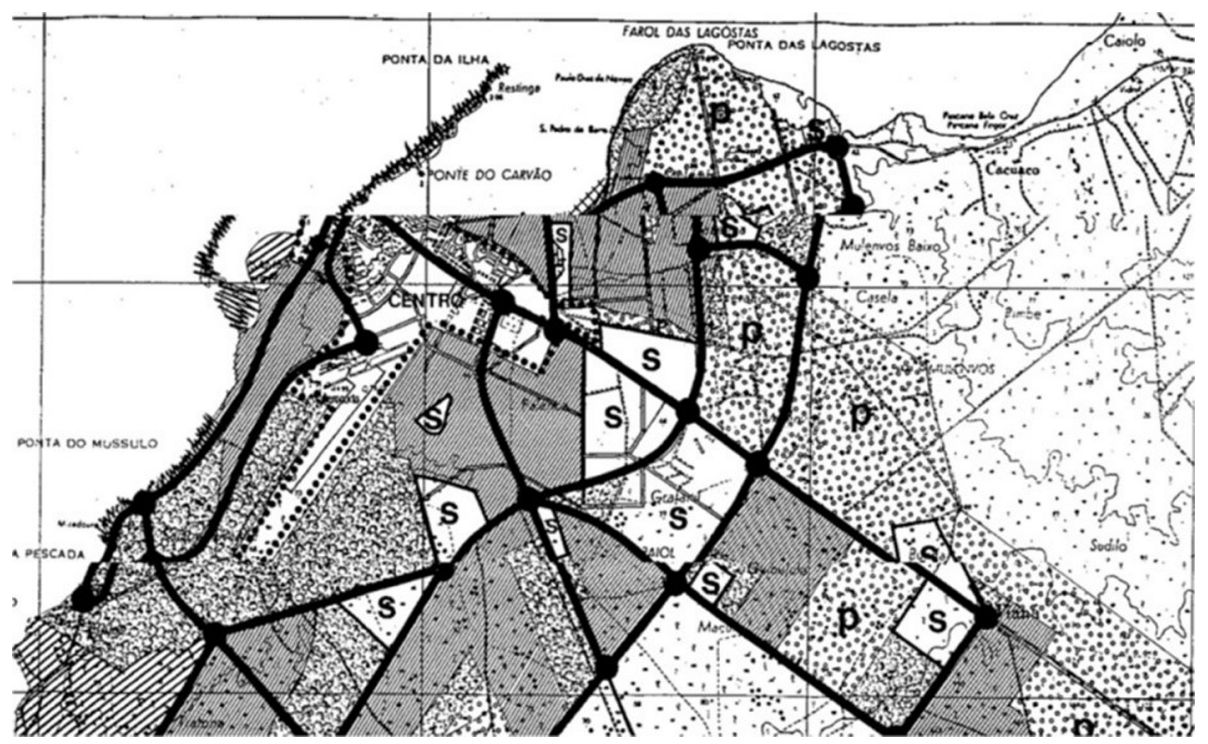

Fonte: www.bibliotecaterra.angonet.org

Figura 5 - Luanda - Plano Diretor de 1980

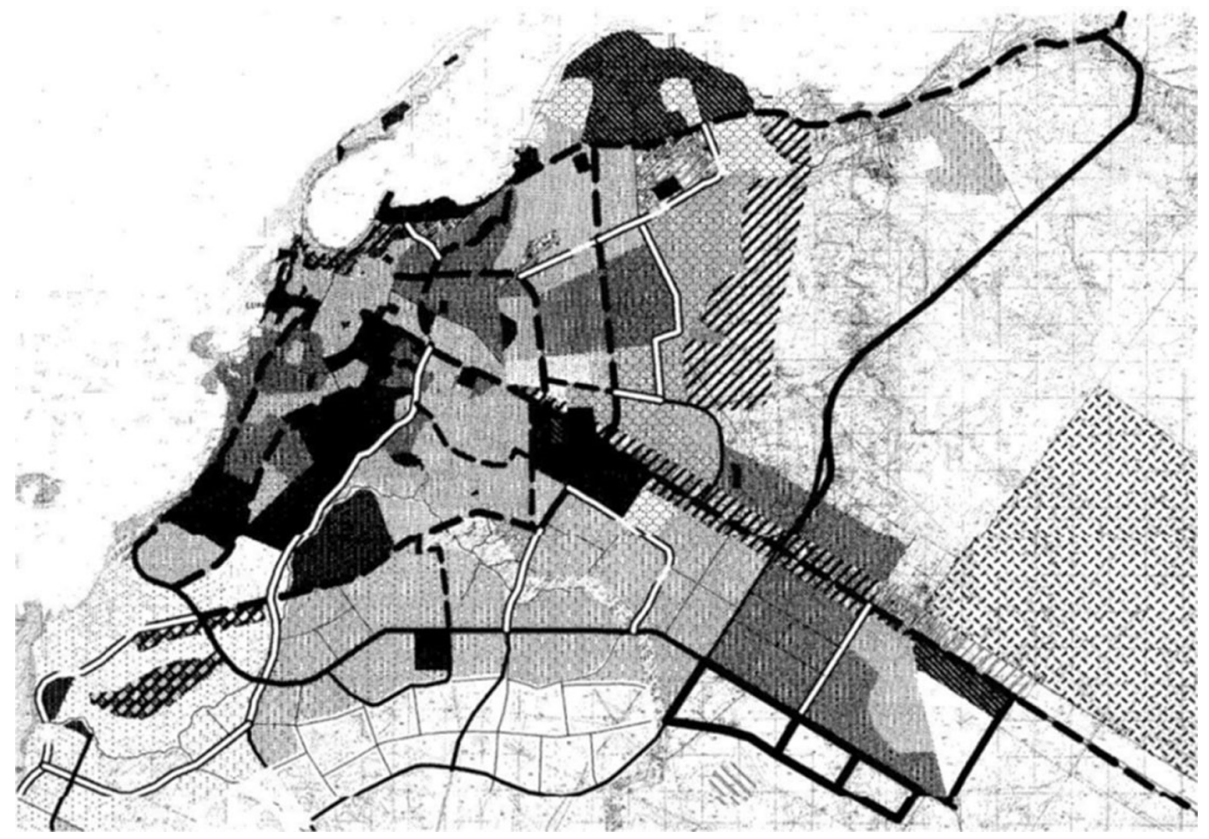

Fonte: www.bibliotecaterra.angonet.org 
Quadro 3 - Resumo dos planos de intervenção urbana da cidade de Luanda

\begin{tabular}{|c|c|c|}
\hline Data & Tipo de plano & Elaboração \\
\hline 1943 & Plano de Urbanização & $\begin{array}{l}\text { - Etienne Grover e David Moreira da Silva } \\
\text { - Aprovado pela Câmara Municipal de Luanda }\end{array}$ \\
\hline 1973 & Plano Diretor para a Cidade de Luanda & $\begin{array}{l}\text { Empresa francesa, a O.T.A.M. (Omnium Technique } \\
\text { d'Aménagement) }\end{array}$ \\
\hline 1979 & Plano Diretor para Luanda & Diretório Nacional de Planeamento Físico \\
\hline 1982 & Lei da Autoconstrução & Estado \\
\hline 1987 & Projeto de Melhoramento do Sambizanga & $\begin{array}{l}\text { Development Workshop (DW) } \\
\text { Departamento Nacional do Urbanismo }\end{array}$ \\
\hline 1995/1997 & $\begin{array}{l}\text { Plano de Gestão do Crescimento Urbano } \\
\text { da Cidade de Luanda }\end{array}$ & $\begin{array}{l}\text { Ministério do Plano, um projeto do Banco Mundial } \\
\text { para o Governo Provincial de Luanda (GPL), } \\
\text { desenvolvido pela Dar al-Handasah }\end{array}$ \\
\hline 1995/1997 & $\begin{array}{l}\text { Plano de Gestão do Crescimento Urbano } \\
\text { da Cidade de Luanda }\end{array}$ & Governo de Luanda \\
\hline Início 2001 & $\begin{array}{l}\text { Plano de Drenagem de Estradas e de Águas } \\
\text { Pluviais para um Musseque Piloto }\end{array}$ & $\begin{array}{l}\text { Ministério do Urbanismo e Habitação e programa } \\
\text { de autoconstrução dirigida }\end{array}$ \\
\hline 2002 & $\begin{array}{l}\text { Plano Estratégico do Solo e de Reabilitação } \\
\text { de Luanda }\end{array}$ & Gabinete de Obras Especiais (GOE) \\
\hline 2003 & $\begin{array}{l}\text { Estudo de desenvolvimento urbano } \\
\text { do município do Cazenga }\end{array}$ & DAR al-Handasah \\
\hline 2006 & Nova Cidade de Luanda & China International Fund Ltd \\
\hline 2007 & $\begin{array}{l}\text { Diretrizes e estratégias para o Plano de } \\
\text { Desenvolvimento 2009/2013, para Luanda } \\
\text { e Bengo }\end{array}$ & Dar al-Handasah \\
\hline $2008 / 2009$ & $\begin{array}{l}\text { Plano de Gestão do Crescimento Urbano } \\
\text { da Cidade de Luanda }\end{array}$ & $\begin{array}{l}\text { Dar al-Handasah Ministério do Ambiente } \\
\text { e Urbanismo }\end{array}$ \\
\hline 2008 & $\begin{array}{l}\text { Projeto de Construção de Um Milhão } \\
\text { de Casas até o ano } 2012 \\
\text { "Meu Sonho, Minha Casa" }\end{array}$ & Programa Nacional de Urbanismo e Habitação \\
\hline 2012 & Plano Nacional de Desenvolvimento & $\begin{array}{l}\text { Ministério do Planejamento e do Desenvolvimento } \\
\text { Territorial de Angola }\end{array}$ \\
\hline 2015 & $\begin{array}{l}\text { Plano Diretor Geral Metropolitano de } \\
\text { Luanda }\end{array}$ & $\begin{array}{l}\text { Governo de Angola, Governo Provincial de Luanda, } \\
\text { Instituto do Planeamento e Gestão Urbana de } \\
\text { Luanda, Urbinvest }\end{array}$ \\
\hline
\end{tabular}

Fonte: Development Workshop (2005), Betencourt (2011) e Luanda (2015). Elaboração própria (2018). 
A razão de se depositar, nos planos, meios cruciais para o desenvolvimento, num espaço em que ainda Ihe são alheias questões como democracia, participação popular, liberdade humana e outros, construiu a ideia de que a mera existência de planos representa a ordem e a solução dos problemas urbano/ regionais e que a sua ausência se constitui na desordem socioespacial.

Sabe-se, porém, que a ordem estrutural do espaço de Angola é dada pelo modelo governativo centralizado, repleto de incongruências (Oliveira, 2015) e que se vale da condição despolitizada da cidade e do capitalismo tardio, para engendrar um planejamento imposto por uma governamentalidade de orientação ideológica esquizofrênica - ora de essência capitalista neoliberal, mas arcaica e centralizada nas suas formas de controle, redistribuição e acumulação; ora socialista, mas neoliberal em suas práticas - que substituiu o debate, o desacordo e o dissenso por uma série de tecnologias de governar, geralmente compradas de fora: uma gestão tecnocrática. Por assim ser, a elaboração e aprovação do PDGML 2015-2030 - que se enquadra perfeitamente nesse retrato e que foi euforicamente comentado e ovacionado, não apenas pela classe política envolvida, mas por leigos, administração pública e, principalmente, pelos principais atores econômicos e imobiliários nacionais e internacionais, que viam, neste, uma oportunidade de realização de seus anseios - incorre em um fracasso determinado como instrumento de reestruturação e desenvolvimento.

Além disso, a grande questão para Angola é que as ações do Estado se confundem com os interesses de agentes privados que, na maioria dos casos, também são os próprios agentes do Estado. Esse fato pode ser notado ao analisar os objetivos do Plano Diretor Metropolitano de Luanda que, além de intencionar a acomodação dos 12,9 milhões de pessoas, previstos para 2030, tem o objetivo de criar condições para "apresentar a capital como uma oportunidade para atrair novos investimentos internacionais" (Luanda, 2015, p. 32). Ou seja, existe uma preocupação maior em apresentar a cidade como um cardápio urbano, mais do que resolver os problemas sociais e urbanos da população mais vulnerável. 0 que leva a questionar os interesses de um planejamento que apenas prioriza os interesses do capital global

Pode-se dizer que o Plano Diretor Geral Metropolitano de Luanda 2015-2030 (Luanda, 2015) é o primeiro documento mais importante e completo da instituição da região metropolitana, até então, lançado pelo Ministro de Estado e chefe da casa civil e que foi aprovado pelo Conselho de Ministros em 2015. O plano fundamenta-se sobre três pilares: "cidade habitável", "nossa cidade bonita" e "cidade internacional". Propõe-se, nesse plano, a organização do espaço urbano por meio de novas estruturas e padrões de uso e ocupação do solo, motivada pelo crescimento populacional e pela expansão urbana para além dos limites territoriais da província (Figura 6).

A intenção de organizar espaços precários, que já estão para além dos limites normais do território urbano, pressupõe a ocorrência de processos e dinâmicas inerentes à metropolização, independentes do planejamento metropolitano. Ou seja, nesse caso, o plano caracteriza-se mais como um instrumento remediador que nunca alcança, de fato, seus princípios. Nesse cenário, é preciso compreender que esses processos 
Figura 6 - Região metropolitana de Luanda e expansão urbana em 2013

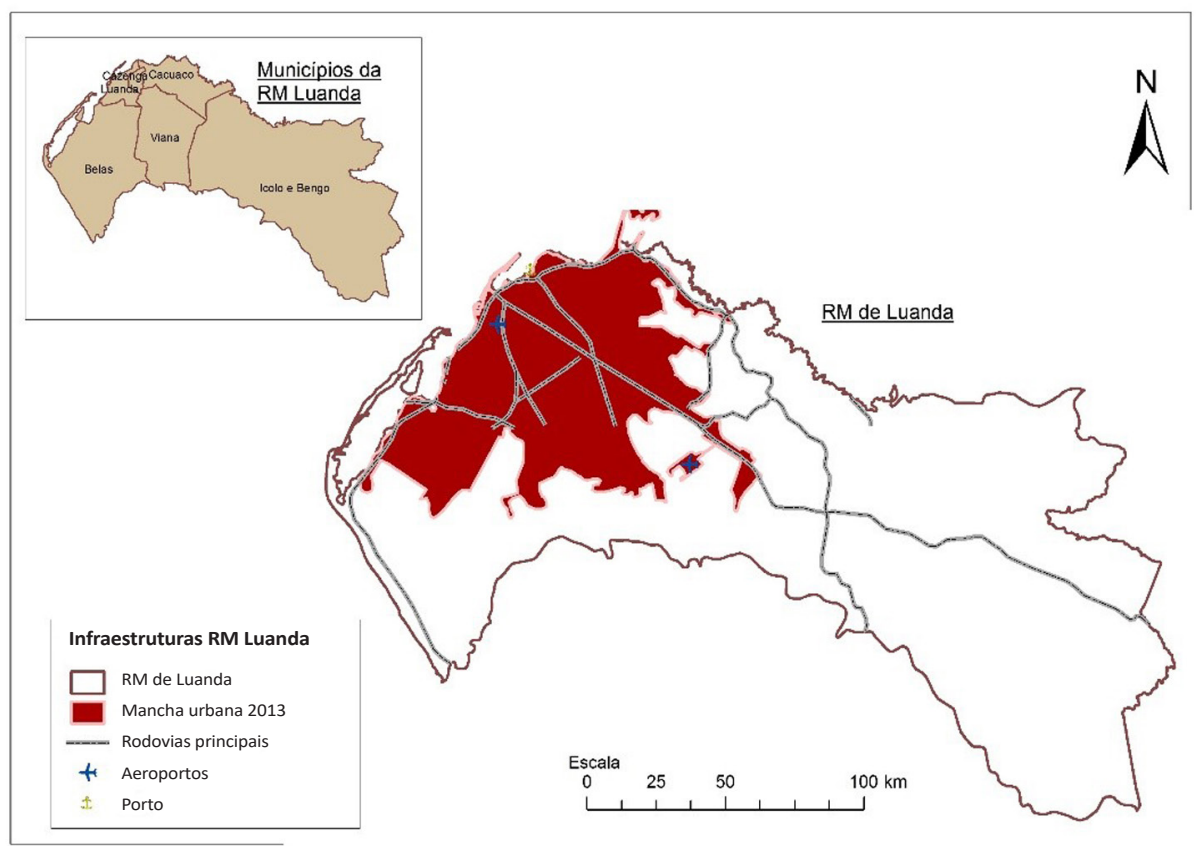

Fonte: www.mapmaker.com e Development Workshop (2013). Elaboração própria.

metropolitanos não acontecem de modo ensimesmados ou espontâneos, mas são influenciados pela própria lógica governativa dentro de interesses bem dirigidos.

É quase um consenso nacional a ideia de que o período pós-guerra seguido de um copioso crescimento econômico deveria proporcionar um grande desenvolvimento. Além disso, o fascínio das elites angolanas e até de boa parte da população quanto às mudanças urbanas e socioeconômicas foi encorajado pelo discurso do poder executivo sob a fala do ex-presidente da República (José Eduardo dos Santos), quando dizia:
Os angolanos são especiais. Apesar da dimensão e da complexidade da tarefa de reconstrução nacional, agora que estamos em paz havemos de encontrar o caminho, de maneira que nos próximos dez, quinze, vinte ou trinta anos possamos mudar radicalmente a situação em Angola e garantir a cada angolano uma vida melhor. (Abrantes, 2009, p. 99)

Passaram-se mais de 17 anos, e a única "vida melhor" garantida é o crescimento do status social e financeiro de pequena e seleta parcela da população ligada ao poder político/ militar (Oliveira, 2015), que exibe, dentro ou 
fora do país, sua glamurosa vida urbana, atípica daquela a que originalmente pertencem, na qual controversamente se convive com o atraso e a pobreza, a precariedade e a informalidade do espaço e das atividades e serviços socioeconômicos. Verificam-se, aqui, uma utopia perpétua e a falta de coerência no discurso que contribui para a cooptação da identidade sociocultural. Segundo Hobsbawm (1995, p. 199), essa contradição é típica dos "países atrasados que procuram ascender à modernidade e são caracterizados, de maneira geral, pela falta de originalidade das suas ideias, embora nas suas práticas não sejam necessariamente assim".

De toda forma, esta análise não tem o objetivo de atrapalhar ou ofuscar os esforços do Estado na tentativa de melhorar as condições urbanas e sociais de Angola e Luanda em particular. E não é, igualmente, nosso interesse contrariar a ideia de elaboração de planos diretores como instrumento de fomento do desenvolvimento. Compreende-se que, para o contexto de Luanda e Angola em geral, o planejamento constitui um instrumento necessário e fundamental para a reestruturação urbana e para o desenvolvimento metropolitano. No entanto, é preciso uma coragem extra, para perceber, explorar e assumir novos paradigmas de planejamento para além daquele, preso às regras do planejamento convencional e top-down. E, embora Luanda tenha todas as características que a permitem ser classificada como região metropolitana, existem peculiaridades e especificidades que devem ser tomadas em conta para o desenvolvimento de um espaço urbano equânime, democrático e resiliente, dentro das reais necessidades e condições culturais, econômicas e sociais do lugar.
Segundo Vasconcellos (2012), o planejamento do desenvolvimento urbano é determinado por fatores como: processos migratórios, sistema político e econômico, setor financeiro, indústria, comércio e serviços, valor e uso da terra urbana, interesse e necessidades das pessoas, construção civil, políticas de estado, sistema existente de transporte e trânsito. Aspectos que em Luanda, como já abordado, são em grande medida dominados pela informalidade estrutural que desenha o espaço urbano/metropolitano e engendra, por meio de suas múltiplas funções socioconectivas, um sistema híbrido que configura a identidade da paisagem, das relações sociais e de um "terceiro espaço" (Bhabha, 1990) que é o ponto de confluência que impulsiona as dinâmicas quotidianas dessa metrópole. Sob esse raciocínio, entende-se que essa conformação híbrida se constitui então, para nós, na abordagem que costura a ideia - força central para o planejamento e desenvolvimento das metrópoles do Sul global. Uma ideia baseada na combinação dos modos e lógicas informais da produção do espaço, com a racionalidade do planejamento formal.

Assim, o planejamento híbrido aqui proposto como instrumento de desenvolvimento urbano/regional, constitui-se como um vetor de inclusão nos mais variados níveis e escalas espaciais, capaz de promover as mudanças reais do espaço. $E$ torna-se em um instrumento de compreensão dos processos de apropriação do espaço e das complexas relações que impulsionam as transformações dos modos de vida. A hibridação com base na combinação entre os sistemas urbanos formais e informais, em detrimento do planejamento top-down, passa a ser um fator de contribuição para um novo olhar e compreensão do espaço 
das metrópoles periféricas do Sul global, na medida em que é entendida além das lógicas inerentes às estratégias de sobrevivência. Ou seja: a inclusão dos modos, formas e lógicas da informalidade que estruturam o espaço precisam ser abordadas e valorizadas em um mesmo nível do planejamento formal.

Uma das formas práticas de aplicação desse conceito de planejamento é, no caso de Angola, por meio das autarquias - um modelo de organização e gestão administrativa do território que tem sido alvo de debates por diversos estudiosos. Previstas (ainda que de forma incompleta) pela Lei Constitucional de 1992 e pela Constituição de 2010 (Orre, 2014), esse modelo foca na premissa da descentralização e governança compartilhada ${ }^{6}$ como o caminho mais adequado para o desenvolvimento urbano/regional equânime e democrático. No entanto, até o presente momento, esse processo ainda não teve início, estando previstas as primeiras eleições autárquicas para 2020, em meio a uma série de incoerências e desconhecimento dos elementos técnico/legais que vão amparar tal modelo e permitir compreender a relação entre os aspectos institucionais com os fenômenos e dinâmicas urbanas.

Diversos estudiosos afirmam ser difícil um desenvolvimento equânime sem uma descentralização do poder administrativo (Cain, 2015; Orre, 2014; Rocha, 2010), uma vez que o modelo centralizado e autocrático não permite um planejamento participativo e democrático. E, ao tomar as decisões de cima para baixo, o poder governativo influi-se em um cenário "em que a realização de mudanças ignora a opinião dos beneficiários, são artificiais e mais propensas ao fracasso" (Pereira, 2013, p. 249).

Segundo Orre (2014), o termo desconcentração a que se refere a constituição resvala do verdadeiro propósito da autarquização. A Constituição de 2010 prevê, nas suas normas transitórias, a introdução do modelo gradualista que se tornou a pauta central do debate político além das discussões da desconcentração e descentralização. Segundo Orre (ibid.), a desconcentração limita-se a criar alguma autonomia administrativa dentro da hierarquia estatal e não tem, como objetivo, criar maior autonomia política local, como seria a descentralização democrática, que permite maior governação compartilhada e participativa. A governação compartilhada e participativa é a chave para a organização especial baseada na combinação entre os modos formais e informais, dentro de um sistema que precisa aceitar as peculiaridades e especificidades do espaço como produtos do próprio espaço e fundamentais para o fortalecimento do sistema metropolitano.

No entanto, a dificuldade consiste no pouco debate e incompletudes que existem quanto à própria questão das autarquias, tais como:

\begin{abstract}
Qual o desenho institucional? Qual o sistema eleitoral? Quais atribuições, prerrogativas e competências iriam ter uma autarquia? Quais fontes de rendimento iriam ser concedidas às autarquias? Como iria conviver e dividir tarefas e autoridade com os representantes dos órgãos locais do Estado? (Ibid., p. 7)
\end{abstract}

Além disso, apesar de ainda estar em construção, o princípio das autarquias e o conceito do planejamento híbrido se apresentam como uma potencial resposta e uma oportunidade capaz de atingir um novo paradigma de planejamento e desenvolvimento para as metrópoles periféricas do Sul global, valorizando as forças e vontades comunitárias de cada 
autarquia ou comunidade, dando voz e sentido de pertencimento aos sujeitos marginalizados da informalidade que, na prática, estruturam o espaço urbano/metropolitano (Castro, 2019). Desta forma, é possível fortalecer as abordagens que emergem das forças e peculiaridades endógenas e constituir um nível multiescalar de diálogo entre a ordem formal institucional e a ordem do habitus sociocultural, entendendo que a criação de autarquias pode responder à necessidade de reestruturar instituições de governação mais democráticas, capazes de garantir direitos e serviços públicos com um mínimo de autonomia, capacidade e sofisticação.

\section{Considerações finais}

Este artigo procurou compreender e demonstrar as ações de planejamento que ocorrem em Angola como estratégias de desenvolvimento territorial, bem como analisar os processos e dinâmicas socioespaciais que deram origem à metropolização de Luanda, fundamentada sobre as diretrizes do PND (20122017) e as disposições do PDGML (20152030). Nesse sentido, considerou-se, antes, a compreensão das complexidades do enredo político, cultural e socioeconômico que caracterizam a área de estudo, como fundamentais para a compreensão da atual conformação territorial de Angola.

A fundamentação teórico/bibliográfica evidenciou tendências globais e contemporâneas nos atributos e estilo de vida adotados no espaço urbano de Angola - característica comum aos países periféricos do Sul global, que se debatem com profundos desequilíbrios nas dimensões do território, da sociedade, da economia, da política e de mobilidade. Para o caso de Angola, foi possível identificar esse conjunto no estudo da região metropolitana de Luanda, que concluímos ser a maior representação dos desequilíbrios e assimetrias regionais que o plano de desenvolvimento tenta equalizar no território. Além desse fato, Luanda apresenta-se como objeto principal do planejamento urbano e regional de Angola.

Os desequilíbrios regionais de Angola vêm sendo constantemente explicados por vários estudiosos a partir do argumento da guerra como a causa da atual condição socioespacial. Mas verificou-se que, embora a guerra seja um dos fatores mais marcantes e fundamentais para se estudar a estruturação do espaço urbano e regional de Luanda e o desenvolvimento territorial de Angola, ela não explica toda a complexidade da conjuntura socioespacial contemporânea. Apontam-se, aqui, as ações e os comportamentos do poder governativo, principalmente a partir do pós-guerra, como responsáveis da atual condição de subdesenvolvimento, desigualdades, informalidade e precarização do espaço urbano.

Apontaram-se as incoerências das políticas e dos modelos de desenvolvimento adotados na administração do território, bem como a inação ou descompromisso do Estado com o bem-estar social, como alguns dos fatores de perpetuação da desestruturação e dos desequilíbrios de um espaço cada vez mais excludente, apesar dos grandes ganhos verificados no país, por meio do processo da reconstrução nacional, proporcionado pela passada glória das receitas do petróleo. Ademais, a racionalidade de exploração dos territórios pelo capitalismo neoliberal contemporâneo global, com o qual Angola vem se associando, as especificidades histórico-culturais ligadas ao 
modo de acumulação primitiva das elites angolanas, baseadas na centralização, corrupção sistêmica e nepotismo na gestão das estruturas e dos recursos e potencialidades socioeconômicas do país são, no nosso entender, elementos centrais para a continuidade da precarização urbano/regional do pós-guerra.

Nesse interregno, e de acordo com os dados estudados, afirma-se que as assimetrias do desenvolvimento territorial e as crises urbano/regionais ao que o PND muito se refere são estruturais e históricas. E se perpetuarão, caso se continue adotando um pensamento tecnocrata e neoliberal que não valoriza outros modos de produção de um espaço desigual, com índices socioeconômicos seriamente comprometidos. Ainda mais no atual momento em que se assiste a uma baixa no preço global do petróleo, do qual Angola é completamente dependente.

Quanto ao planejamento urbano/regional de Luanda, nosso foco incidiu na análise de dois aspectos principais.

A primeira refere-se à desconstrução do discurso da desestruturação e precariedade urbana como resultado da falta de planejamento e a falta de capacidade técnica. Verificou-se que o planejamento para o desenvolvimento urbano esteve sempre presente nas ações e agendas do Estado. Porém, na maioria das vezes, as condições em que esses planos eram elaborados e aplicados não eram tão favoráveis. Quanto à falta de capacidade técnica muito anunciada por vários estudiosos, não se sustenta mais para o atual momento do pós-guerra; dado que Angola está inserida numa lógica de trocas socioeconômicas global, em que o meio técnico científico se impõe pela grande mobilidade internacional existente. Ou seja, depois da guerra, a falta de capacidade técnica é um aspeto questionável, uma vez que Angola passou a recorrer a um sem-número de técnicos e tecnologias expatriadas. 0 grande exemplo é a elaboração do PDGML que não foi elaborado em Luanda nem por técnicos angolanos; o processo de reconstrução é outro exemplo clássico, que traz os chineses como principais atores não só do financiamento, mas principalmente da mão de obra. As instituições do Estado estão ou estiveram cheias de consultores formadores e profissionais estrangeiros. Como exemplo, temos o caso de um grande número de consultores e administradores estrangeiros que operou no ex-conselho de administração da Sonangol (maior empresa petrolífera estatal de Angola) liderada por Isabel dos Santos, filha do ex-presidente (José Eduardo dos Santos) entre 2016 e 2017, tendo sido exonerada pelo atual presidente, João Lourenço.

A segunda análise quanto ao planejamento metropolitano de Luanda se conecta ao processo da instituição da região metropolitana de Luanda por meio do PND (Angola, 2012) e principalmente do PDGML (Luanda, 2015). Embora nossa intenção não tenha sido a de esgotar os detalhamentos da análise, concluiu-se que o estudo do planejamento do espaço metropolitano de Luanda é uma abordagem necessária por ser um processo atual, peculiar e, ao mesmo tempo, global. Uma nova conformação espacial constitui-se, como resultado das dinâmicas e processos endógenos, espontâneos ou não, que permitem, no espaço, a estruturação de novos sujeitos sociais e econômicos. Verificou-se que existem muitos aspectos a serem analisados quanto ao uso da terra e à ocupação urbana que configuram Luanda como um verdadeiro caso de macrocefalia urbana, não obstante as intenções do PDGML 2015-2030. 
Em análise, o PDGML (Luanda, 2015) pouco considera, em sua essência, a importância da presença das atuais formas de produção do espaço urbano e representações sociais peculiares, baseadas na informalidade, como é o caso dos transportes, dos serviços e atividades comerciais informais largamente presentes e estruturantes do espaço e ponto de partida para um desenvolvimento urbano equânime. Esse plano se caracteriza mais pela preocupação da venda de uma urbanidade utópica de cidade em desenvolvimento, com grandes potencialidades para trocas internacionais, do que com o verdadeiro desenvolvimento de sua população, cuja maioria vive em condições desumanas.

Por fim, conclui-se que os modelos propostos pelo plano diretor de Luanda, se aplicados, podem, por um lado, causar a coexistência de distintas instâncias de socialização das classes e novos valores de referências. $E$, por outro, podem simplesmente representar uma reprodução da ordem socioespacial neoliberal e global caracterizada pela desigualdade social, desestruturação e exploração precária do território, dada a debilidade das estruturas legais do Estado. Assim, o processo de planejamento metropolitano de Luanda deve ser, também, um processo social e político dotado de ampla participação popular, no qual o planejamento não seja de cima para baixo, mas um encontro entre as duas ordens que formam o espaço (formal e informal) e constroem o que chamamos de espaço híbrido - uma lógica socioespacial que já faz parte da dinâmica quotidiana de produção e estruturação da cidade de Luanda. É, a partir dessa lógica híbrida e informal (não planejada), que se sugere pensar as metrópoles do Sul global de modo inclusivo e democrático. Pois o desenvolvimento só é possível quando há plena liberdade, acessibilidade e ausência da condição vitimizante da população, além da redistribuição equilibrada dos recursos e oportunidades do espaço.

\section{[I] https://orcid.org/0000-0003-0176-9017}

Universidade do Vale do Paraíba, Instituto de Pesquisa e Desenvolvimento, Programa de Pós-Graduação em Planejamento Urbano e regional. São José dos Campos, SP/Brasil. jccaleia2@gmail.com

\section{[II] https://orcid.org/0000-0002-8477-1739}

Universidade do Vale do Paraíba, Faculdade de Engenharias, Arquitetura e Urbanismo, Programa de Pós-Graduação em Planejamento Urbano e Regional. São José dos Campos, SP/Brasil. pauloromano@univap.br 


\section{Notas}

(1) Verificar Castro (2015).

(2) Geralmente, os governadores provinciais desempenham também a função de primeiros secretários provinciais do partido no poder. Ou seja, são os líderes e representantes políticos máximos das províncias. O que compromete, de acordo com especialistas, a dedicação às funções do Estado para às quais foram designados (Kaliengue, 2016).

(3) As instituições são dotadas de uma racionalidade segundo a qual, para qualquer cidadão qualificado alcançar algum cargo público com o mínimo de prestígio, na maioria das vezes, é necessário que esteja afiliado ao partido no poder ou que tenha algum grau de influência político-partidária. Embora seja a regra conhecida na arena social e política, esse princípio nem sempre é falado abertamente.

(4) O termo "musseques" é usualmente aplicado às zonas suburbanas, ocupadas pelas populações economicamente desfavoráveis. É aplicado, ainda, para formas de urbanização improvisada, precária e em permanente expansão (Development Workshop, 2005). E, embora o termo tenha origem na geologia das terras arenosas e vermelhas nas periferias de Luanda, é equivalente a favelas (Brasil) ou slums (no termo Inglês).

(5) Resolução n. 27/2000 de 24 de novembro, Diário da República, I Série - n. 50. Development Workshop (2005, p. 73).

(6) "Mesmo a Constituição de 2010 dando resposta a uma boa parte das perguntas supracolocadas e isto com apenas um debate público mínimo sobre o assunto, ela determina um modelo específico, fechando a porta para o que deveria constituir uma discussão pública significativa" (Orre, 2014, p. 7).

\section{Referências}

ABRANTES, J. M. (2009). Jose Eduardo dos Santos e os desafios do seu tempo. Palavras de um estadista, 1979-2009. Luanda, Maianga.

ALONSO, S. (2011). Macrocefalia urbana. Brasil Escola. Disponível em: <http://brasilescola.uol.com.br/ geografia/macrocefalia-urbana.htm>. Acesso em: 6 out 2016.

AMARAL, I. do (2005). Importância do setor informal da economia urbana em países da África subsariana. Finisterra, XL, 79, pp. 53-72. Lisboa.

BANCO MUNDIAL (2020). Indicadores do Desenvolvimento Mundial. Disponível em: <https://www. google.com/publicdata/explore?ds=d5bncppjof8f9_\&met_y=sp_pop_totl\&idim=country:AGO: MOZ:DZA\&hl=pt\&dl=pt>. Acesso em: 3 maio 2020.

BARBOSA, J. L. (2015). "A mobilidade urbana no processo de metropolização: um ensaio crítico sobre as condições da produção social do espaço urbano no contemporâneo". In: FERREIRA, A.; RUA, J.; MATTOS, R. C. de (orgs.). Desafios da metropolização do espaço. Rio de Janeiro, Consequência. 
BETTENCOURT, A. C. de A. (2011). Requalificação e reabilitação de áreas urbanas críticas - os musseques de Luanda. Dissertação de mestrado. Lisboa, Universidade de Lisboa.

BHABHA, H. (1990). Terceiro espaço. Londres, Lawerence \& Wishart.

BIBLIOTECATERRA. Planos diretor de Luanda DW. Disponível em: <www.bibliotecaterra.angonet.org>. Acesso em: 7 dez 2014.

BRAGA, R.; CARVALHO, P. (2004). “Cidade: espaço da cidadania”. In: GIOMETTI, A. B. R.; BRAGA, R. (orgs.). Pedagogia Cidadã: Cadernos de Formação: Ensino de Geografia. São Paulo, Unesp-Propp, Disponível em: http://redbcm.com.br/arquivos/bibliografia/cidade\%20espa\%C3\%A7o\%20 da\%20cidadania\%20rbraga11.pdf. Acesso em: 27 nov 2016.

BRESSER-PEREIRA, L. C. (2004). O conceito de desenvolvimento do ISEB rediscutido. Dados. Rio de Janeiro, v. 47, n. 1, pp. 49-84. Disponível em: <https://www.scielo.br/scielo.php?script=sci_ arttext\&pid=S0011-52582004000100002\&lng=pt\&tlng=pt>. Acesso em: 6 dez 2016.

CAIN, A. (2011). Em Luanda: alto para os pobres e baixo para ricos - preço da água. Novo Jornal, edição de 19 de agosto. Disponível em: https://www.angonet.org/dw/sites/default/files/online_ lib_files/Director\%20de\%20DW\%20Intervista\%20\%20sobre\%20agua\%20e\%20justica\%20-\%20 NovoJornal\%2019\%20Agosto\%202011.pdf. Acesso em: 24 abr 2016.

(2013). Mercados de terra urbana e microfinanças para habitação em Angola. Development Workshop e Faculdade de Economia da universidade Agostinho Neto. Disponível em: http:// novafrica.org/wp-content/uploads/2015/02/Allan-Cain-PP.pdf. Acesso em: 24 abr 2016.

(2014). African urban fantasies: past lessons and emerging realities. Environment and Urbanization, v. 26, n. 1, pp. 561-567. Disponível em: https://www.researchgate.net/publication/273193414_ African_urban_fantasies_Past_lessons_and_emerging_realities. Acesso em: 26 abr 2016.

(2015). Allan Cain sobre ambiente urbano e saneamento em Luanda. DW Angola. Disponível em: <https://www.dw.angonet.org/forumitem/allan-cain-sobre-ambiente-urbano-e-saneamentoem-luanda>. Acesso em: 28 maio 2017.

CALDEIRA, T. P. (2017). Peripheral urbanization: autoconstruction, transversal logics and politics in cities of the global south. Environment and Planning D: Society and Space, v. 35, n. 1, pp. 3-20.

CARMO, S. de C. B. do (2004). Baixada santista: câmara e agenda 21. Disponível em: http://www. novomilenio.inf.br/baixada/bs001c7.htm. Acesso em: 21 set 2016.

CASTRO, J. C. (2015). Configuração socioespacial como expressão de conflitos: expansão urbana de Luanda e o planejamento territorial de Angola. Dissertação de mestrado. São José dos Campos, Universidade do Vale do Paraíba.

(2019). O papel do transporte informal na (re)estruturação dos sistemas de mobilidade metropolitana em cidades do sul global/estudo de caso: Luanda, Angola. Tese de doutorado. São José dos Campos, Universidade do Vale do Paraíba.

CASTRO, J. C.; RESCHILIAN, P. R.; ZANETTI, V. (2018). Os candongueiros e a “desordem" urbana de Luanda: uma análise sobre a representação social dos transportes informais. Revista Brasileira de Gestão Urbana, v. 10, n. 1, pp. 7-21.

CEIC - UCAN (Centro de Estudos e Investigação Científica da Universidade Católica de Angola) (2013). Relatório económico anual de Angola. Luanda, Texto editores. Disponível em: http://www.ceicucan.org/wp-content/uploads/2014/07/relatorio_Economico_Angola_2013_FINAL.pdf. Acesso em: 20 mar 2014. 
CHRISTENSEN, P. et al. (2011). Children, mobility, and space: using GPS and mobile phone technologies in ethnographic research. Journal of Mixed Methods Research, v. 5, n. 3, pp. 227-246. Disponível em: <https://journals.sagepub.com/doi/10.1177/1558689811406121>. Acesso em: 29 dez 2017.

CONSTITUIÇÃO DA REPÚBLICA DE ANGOLA (1992). Lei Constitucional de 1992. Angola. Disponível em: < http://cedis.fd.unl.pt/wp-content/uploads/2016/01/LEI-CONSTITUCIONAL-1992.pdf>. Acesso em: 17 nov 2017.

(2010). Assembleia Constituinte. Disponível em: http://imgs.sapo.pt/jornaldeangola/content/ pdf/CONSTITUICAO-APROVADA_4.2.2010-RUI-FINALISSIMA.pdf. Acesso em: 13 nov 2016.

COSTA, M. A (2013). “Quarenta anos de Regiões Metropolitanas no Brasil: um breve balanço exploratório". In: COSTA, M. A.; TSUKUMO, I. T. L. (orgs.). 40 anos de Regiões Metropolitanas no Brasil. Brasília, Ipea.

DAVIS, M. (2006). Planeta favela. São Paulo, Boitempo.

DEVELOPMENT WORKSHOP (2005). Terra: reforma sobre a terra urbana em Angola no período pós-guerra. Pesquisa, advocacia e políticas de desenvolvimento. Luanda.

FURTADO, C. (2002). Em busca de novo modelo: reflexões sobre a crise contemporânea. São Paulo, Paz e Terra.

FREITAS, R. (2009). Regiões Metropolitanas: uma abordagem conceitual. Humanae, v. 1, n. 3, pp. 44-53.

HAERINGER, P. (1998). “La mégapolisation: un autre monde, un nouvel apprentissage”. In : BURDÈSE J. C.; ROUSSEL M. J.; SPECTOR, T.; THEYS, J. (eds.). De la ville à la mégapole: essor ou déclin des villes au 21ème siècle? França. IRD. Disponível em: <http://horizon.documentation.ird.fr/exldoc/pleins_textes/pleins_textes_7/b_fdi_55-56/010021362.pdf>. Acesso em: 14 dez 2016.

HOBSBAWM, E. (1995). Era dos extremos. O breve século XX. São Paulo, Companhia das Letras.

INE - Instituto Nacional de Estatística (2011). Inquérito Integrado sobre o Bem-Estar da População. Luanda, INE.

(2014). Censo - resultados preliminares, recenseamento geral da população e habitação. Luanda, INE.

(2016). Recenseamento Geral da População e Habitação - Resultados definitivos do Censo. Luanda, INE

(2018). Objectivos de Desenvolvimento Sustentável: Relatório de Indicadores de Linha de Base Agenda 2030. Luanda, INE. Disponível em: <file:///C:/Users/JoseCaleia/Desktop/UNDP_AO_ Relat\%C3\%B3rio\%200DS_IND_BASE_FINAL\%202018.pdf>. Acesso em: 12 dez 2018.

IPGUL - Instituto de Planejamento e Gestão Urbana de Luanda (2015). PDGML - Plano Diretor Geral Metropolitano de Luanda 2015-2030. Luanda, IPGUL.

JACCOUD, L. (2001). Experiências Internacionais em Política Regional: o caso da França. Brasília, Ministério do Planejamento, Orçamento e Gestão; Instituto de Pesquisas Econômicas Aplicadas.

JAGLIN, S.; DIDIER, S.; DUBRESSON, A. (2018). Métropolisations en Afrique subsaharienne: au menu ou à la carte? Métropoles. ENTPE, Hors Série 2018 - 10 ans: Numero anniversaire.

KALIENGUE, I. (2016). MPLA mantém equipa para eleições em 2017. Angonoticias. Disponível em: <http://www.angonoticias.com/Artigos/item/50948/mpla-mantem-equipa-para-eleicoesem-2017>. Acesso em: 6 dez 2016. 
KLINK, J. (2013). “Por que as Regiões Metropolitanas continuam tão ingovernáveis? Problematizando a reestruturação e o reescalonamento do Estado Social-Desenvolvimentista em espaços metropolitanos". In: FURTADO, A. F.; KRAUSE, C.; FRANÇA, C. B. de (eds.). Território metropolitano, políticas municipais. Brasília, Ipea.

LEI CONSTITUCIONAL DE 1992. Angola. Disponível em: <http://cedis.fd.unl.pt/wp-content/uploads/2016/01/ LEI-CONSTITUCIONAL-1992.pdf>. Acesso em: 17 nov 2017.

LENCIONI, S. (2006). “Da cidade e sua região à cidade-região”. In: SILVA, J. B. da; LIMA, L. C.; ELIAS, D. (orgs.). Panorama da geografia brasileira. São Paulo, Annablume.

(2015). "Metropolização do espaço e a constituição de megarregiões". In: FERREIRA, A.; RUA, J.; MATTOS, R. C. (orgs.). Desafios da metropolização do espaço. Rio de Janeiro, Consequência.

LOPES, C. M. (2011). Candongueiros e Kupapatas: Acumulação, risco e sobrevivência na economia informal em Angola. Cascais, Principia.

LUKOMBO, J. B. (2011). Crescimento da População em Angola: Um olhar sobre a situação e dinâmica populacional da cidade de Luanda. Revista de Estudos Demográficos, n. 49, pp. 53-67. Lisboa, INE.

MAP MAKER. The Pier, Carradale, Kintyre, PA28 6SQ, UK. Disponível em: www.mapmaker.com. Acesso em: 20 out 2014.

MYERS, G. (2011). African Cities: Alternative Visions of Urban Theory and Practice. Zed Books Ltda.

MOURA, R. (2009). Arranjos urbano-regionais no Brasil: uma análise com foco em Curitiba. Tese de doutorado. Curitiba, Universidade Federal do Paraná.

MOURA, R; FIRKOWSKI, O. L. C. de F. (2001). Metrópoles e Regiões metropolitanas: o que isso tem em comum? In: IX ENCONTRO NACIONAL DA ANPUR. Anais... Rio de Janeiro, v. 5, pp. 105-114.

OLIVEIRA, R. S. de (2015). Magnífica e miserável: Angola desde a Guerra Civil. Lisboa, Tinta-da-China.

ORRE, A. (2014). Autarquias em Angola: Qual o problema do "Gradualismo". Michelsen Institute. Disponível em: <http://www.cmi.no/publications/file/4930-autarquias-em-angola.pdf>. Acesso em: 10 nov 2014.

PEREIRA, E. M. (2013). Planejamento urbano no Brasil: conceitos, diálogos e práticas. Chapecó, Argos.

PERROUX, F. (1950). Espaço econômico: teoria e aplicações. The Quarterly Journal of Economics, v. 64, edição 1, pp. 89-104. Disponível em: <https://doi.org/10.2307/1881960>. Acesso em: 12 fev 2014.

(1967). "Teoria dos polos de desenvolvimento". In: SCHWARTZMAN, J. (org.) Economia Regional. Belo Horizonte, Cedeplar.

PIETERSE, E. (2011). Grasping the unknowable: coming to grips with African urbanisms. Social Dynamics, v. 37, n. 1, pp. 5-23. Disponível em: < https://www.tandfonline.com/doi/abs/10.1080/02533952. 2011.569994>. Acesso em: 19 mar 2017.

PNUD (1999). Relatório do Desenvolvimento Humano. Lisboa, Trinova.

PNUD - RELATÓRIO DO DESENVOLVIMENTO HUMANO (2014). Sustentar o progresso humano: reduzir as vulnerabilidades e reforçar a resiliência. Nova York.

REPÚBLICA DE ANGOLA (2011). Lei n. 29/11, de 1o de Setembro - Lei de Alteração da Divisão Político-administrativa das províncias de Luanda e Bengo. Luanda, Ministério do Urbanismo e Habitação.

(2012). Plano Nacional de Desenvolvimento 2013-2017. Luanda, Ministério do Planeamento e do Desenvolvimento. 
RIBEIRO, L. C. de Q; SANTOS JUNIOR, O. A. dos (2007). As metrópoles e a questão social Brasileira. Rio de Janeiro, Revan, Fase.

(2010). As metrópoles e a questão social brasileira. Rio de Janeiro, Revan, Fase.

ROCHA, M. J. A. da (2004). Opiniões e Reflexões. Colectâneas de artigos, Conferências e Palestras Sobre Angola, África e o Mundo. Luanda, UCAN, Centro de Estudo e Investigação Cientifica.

(2010). Desigualdades e assimetrias regionais em angola - Os factores de competitividade territorial. Luanda, Ceic-Ucan.

(2014). As perspectivas de crescimento económico de Angola até 2020. CEIC. Working Paper n. 2. Luanda, Ceic-Ucan.

(2015). China/Sonangol/Crescimento Económico: 3 assuntos da máxima actualidade. CEIC (Centro de Estudos e Investigação Científica - Universidade Católica de Angola. Disponivel em: https:// studylibpt.com/doc/5053558/china-sonangol-crescimento-econ\%C3\%B3mico--3-assuntos---ceic. Acesso em: 12 nov 2017

(2017). A economia angolana em 2015, 2016 e 2017. Luanda, Universidade Católica de Angola. ROCHEFORT, M (2003). Regionalização e rede urbana. Curitiba, UFPR.

ROY, A. (2005). Urban Informality: toward an epistemology of planning. Journal of the American Planning Association, v. 71, n. 2, pp. 147-158. Disponível em: <https://www.tandfonline.com/ doi/abs/10.1080/01944360508976689>. Acesso em: 20 mar 2018.

SANTOS, M. (1988). Metamorfoses do espaço habitado. São Paulo, Hucitec.

(2000). Por uma outra globalização: do pensamento único à consciência universal. São Paulo, Record.

SCHUBERT J. (2016). A culture of immediatism: co-optation and complicity in post-war Angola, Ethnos, v. 83, n. 1, pp. 1-19. Disponível em: <https://www.tandfonline.com/doi/fu II/10.1080/00141844.2015.1133687>. Acesso em: 17 abr 2018.

SILVEIRA, M. L. (2015). "Metropolização e circuitos da economia urbana”. In: FERREIRA, A.; RUA, J.; MATTOS, R. C. de (orgs.). Desafios da metropolização do espaço. Rio de Janeiro, Consequência.

SINGER, P. (1998). Economia política da urbanização. São Paulo, Contexto.

SOUZA. M. L. de (2013). Os conceitos fundamentais da pesquisa socioespacial. Rio de Janeiro, Bertrand Brasil.

VASCONCELOS, E. A. de (2005). A cidade, o transporte e o trânsito. São Paulo, Prolivros.

(2012). Mobilidade urbana e cidadania. Rio de Janeiro, Senac Nacional.

VILLAÇA, F. (2005). As ilusões do plano diretor. São Paulo, USP.

WATSON, V. (2014). African urban fantasies: dreams or nightmares? Environment and Urbanization, v. 26, n. 1, pp. 215-231. Disponível em: <https://journals.sagepub.com/doi/ full/10.1177/0956247813513705>. Acesso em: 22 set 2016.

Texto recebido em 31/out/2018

Texto aprovado em 24/jan/2019 